\title{
Iwona DŁugoszewsKa
}

Akademia Leona Koźmińskiego

\section{PRZESŁANKI OGRANICZENIA WŁADZY RODZICIELSKIEJ NA ZIEMIACH POLSKICH}

\section{UWAGI OGÓLNE NA TEMAT UNORMOWAŃ WŁADZY RODZICIELSKIEJ W Europie OD X do XX WIEKU}

Tradycja regulowania stosunków pomiędzy rodzicami i dziećmi na wzór rzymskiej patria potestas funkcjonowała wśród ludów europejskich jeszcze bardzo długo po upadku cesarstwa. Była ona zauważalna tak w życiu codziennym, jak i w obowiązujących prawach. Ojciec traktowany był nadal jako ten, który od początku daje życie albo śmierć ${ }^{1}$. Przez kilkaset lat rodzina funkcjonująca w kręgu kultury europejskiej podlegała prawie nieograniczonej władzy ojcowskiej. Stosunki w rodzinie były regulowane normami obyczajowymi, religijnymi i wolą ojca, nie zaś przepisami prawnymi, które jeszcze bardzo długo pozostawiały na uboczu tę sferę kontaktów międzyludzkich. Nawet w okresach absolutnej władzy królewskiej władza ojca nad dziećmi miała pierwszeństwo przed władzą króla. Trudno więc w takiej sytuacji doszukiwać się jakichkolwiek regulacji zarówno w zwyczaju, jak i w prawie stanowionym, które prowadziłyby do ograniczenia ojcu

1 Z. WasilkowsKa, Granice ingerencji sqdu opiekuńczego w wykonywanie władzy rodzicielskiej, «Problemy Rodziny» 1983 nr 2, s. 22. 
jego władzy w stosunku do dzieci². Analizując przemiany, jakim podlegało ojcostwo od X do XVIII wieku, należy stwierdzić, że charakteryzowało się ono władzą niemal absolutną. Ugruntowane jeszcze bowiem w średniowieczu, osiagnęło swoje apogeum na przestrzeni wieków od XV do XVII i dzięki harmonizacji prawa kanonicznego, zwyczajowego i rzymskiego można było śmiało mówić o ,złotym wieku" ojca, który trwał w Europie aż do nastania epoki oświecenia. Epoka ta charakteryzowała się bowiem coraz mocniejszym kwestionowaniem uprawnień ojca w rodzinie. Coraz większa była również ingerencja władzy państwowej w funkcjonowanie władzy rodzicielskiej³ Dużym przełomem była w tej mierze Wielka Rewolucja Francuska, która uznała małżeństwo za instytucję świecką, całkowicie podlegającą państwowym przepisom prawnym ${ }^{4}$.

Wbrew pozorom, zmiany te jednak nie wpłynęły tak szybko na przeobrażenia dokonywane w obrębie władzy rodzicielskiej, która mimo iż była regulowana przez prawo cywilne już od końca XVIII wieku, to jednak funkcjonowała nadal na zasadzie podporządkowania dziecka władzy ojcowskiej. Ojciec nadal decydował o wszystkich istotnych sprawach dziecka, tj. o jego miejscu zamieszkania, o kierunku wychowania i wykształcenia, o wyborze przyszłego zawodu. Przysługiwało mu również daleko idące prawo karcenia dziecka. Natomiast ingerencja władzy państwowej ograniczała się jedynie do przypadków, w których przekroczenie uprawnień wynikających z władzy rodzicielskiej prowadziło do zagrożenia zdrowia i życia dziecka. Dopiero druga połowa XIX wieku przyniosła w większości krajów europejskich radykalne zmiany w zakresie stosunków zachodzących między rodzicami

2 Takiemu ukształtowaniu instytucji władzy ojcowskiej sprzyjało wprowadzenie w społeczeństwie stanowym monarchii patrymonialnej. Por. szerzej na ten temat M. SzcZAniecki, Powszechna historia państwa i prawa, Warszawa 1998, s. 53-75; por. również T. KASPRZAK, Tajemnica ojcostwa, «Niebieska Linia» 2004 nr 1, s. 3; M. PŁatek, Prawne korzenie przemocy wobec dziecka, «Niebieska Linia» $2001 \mathrm{nr} 6$, s. 13.

3 Historia ojców i ojcostwa, red. J. Delumeau, D. Roche, Warszawa 1995, s. 25-27.

${ }^{4}$ Konstytucja francuska z 1791 r. stanowiła bowiem, że ,prawo uznaje małżeństwo jedynie za umowę cywilną". 
i dziećmi. Władza rodzicielska stała się przedmiotem bardzo szczegółowych regulacji prawnych, które w sposób wyraźny określały treść tej władzy oraz przesłanki ingerencji w jej zakres ${ }^{5}$.

II. PRZESŁANKI OGRANICZENIA WŁADZY RODZICIELSKIEJ W PRAWIE POLSKIM

1. Instytucja ograniczenia władzy rodzicielskiej w prawie polskim na przestrzeni wieków od X do XVIII

Funkcjonująca w dawnym prawie polskim władza ojcowska była instytucją, z której wynikały dla ojca bardzo szerokie uprawnienia. Wydaje się, iż początkowo i tu także przysługiwało ojcu prawo życia i śmierci, które z biegiem czasu przybrało łagodniejszą formę prawa karcenia. W razie jednak, gdy prawo to okazywało się niewystarczające, ojciec miał możliwość odwołania się do pomocy władz sądowych. Znaczne były również uprawnienia ojca w dziedzinie stosunków majątkowych, a w szczególności to, że nie wolno było synowi zaciągać długów bez jego zezwolenia. Stanowisko matki, ze względu na szeroki zakres władzy ojcowskiej, było ograniczone i sprowadzało się głównie do obowiązku wychowywania dzieci ${ }^{6}$. Dzieci natomiast nie posiadały żadnych praw, były kompletnie podporządkowane ojcu i całkowicie od niego zależne ${ }^{7}$. W czasach przed wprowadzeniem chrześcijaństwa, dzieci obojga płci do siódmego roku życia były pozbawione praw i przebywały pod opieką kobiet. Później chłopcy, po tzw. „postrzyżynach” i nadaniu imienia, przechodzili pod opiekę ojca. Władza oj-

${ }^{5}$ Z. WASILKOWSKA, op. cit., s. 23. Zdaniem autorki, przyczynami tych zmian były: upowszechniające się coraz bardziej równouprawnienie kobiet, które doprowadziło do przekształcenia się władzy ojcowskiej we władzę rodzicielską, czyli władzę ojca i matki sprawowaną na zasadach równości; zmiana spojrzenia na dziecko, które przestało być przedmiotem regulacji prawnych, a stało się podmiotem praw; ewolucja prawa w kierunku większej ingerencji państwa w sprawy rodziny.

${ }^{6}$ K. Lutostański, Prawo cywilne familijne, Warszawa 1932, s. 104.

7 H. Manikowska, J. Tazbirowa, Historia. Średniowiecze, Warszawa 1995, s. 42. 
cowska była na tyle rozległa, że mógł on decydować o życiu i śmierci swoich dzieci, mógł je sprzedać, zastawić, a nawet zabić.

Prawo polskie w okresie średniowiecza było jedynie prawem zwyczajowym ${ }^{9}$. Dopiero w XV wieku doszło do harmonizacji ze sobą praw zwyczajowych, prawa kanonicznego i prawa rzymskiego ${ }^{10}$. Pierwszą kodyfikacją praw, która uwzględniała zarówno normy prawa zwyczajowego, jak i kanonicznego były statuty Kazimierza Wielkiego. Statut wiślicki (małopolski) z 1347 r. ${ }^{11}$ utrzymał przewage ojca w rodzinie, zwłaszcza w stosunkach majątkowych. Z drugiej zaś strony chronił jednocześnie rodzinę. Dzięki bowiem regulacjom zawartym w tym statucie, dzieci nie mogły być maltretowane ani sprzedawane. Statut wprowadzał bowiem surowe kary za zabijanie dzieci, także tych nieślubnych. Ojcu przysługiwało zaś jedynie prawo karcenia dzieci ${ }^{12}$.

Epoka nowożytna charakteryzowała się dalszym rozwojem praw członków rodziny. Ograniczeniu uległa wówczas władza ojcowska. Ojciec nadal pozostawał głową rodziny, której należało się posłuszeństwo i szacunek, jednak dzieci nie mogły być już przez niego zabijane, maltretowane, czy sprzedawane ${ }^{13}$. Tendencje te można było wyraźnie zauważyć w Wielkim Księstwie Litewskim ${ }^{14}$, ponieważ dzieci uważa-

8 T. Bulı́́sKI, Średniowieczny obraz dziecka, «Studia Edukacyjne» 1998 nr 4, s. 94; M. Balcerek, Prawa dziecka, Warszawa 1986, s. 168-183.

9 J. Bardach, B. Leśnodorski, M. Pietrzak, Historia ustroju i prawa polskiego, Warszawa 2000, s. 130.

10 J. Delumeau, D. Roche, op. cit., s. 11.

${ }^{11}$ Statut wiślicki wraz ze statutem wielkopolskim zawierały przepisy dotyczące ustroju państwa oraz prawa sądowego, głównie karnego, gdy natomiast prawo prywatne pozostało nadal domeną norm zwyczajowych. Statuty Kazimierza Wielkiego nie wyczerpały żadnego z działów prawa. Miały one jedynie znaczenie unifikujące oraz wprowadzały, w miejsce przestarzałych, nowe przepisy prawne (por. J. BARDACH, B. LeŚnodorski, M. PietrZaK, op. cit., s. 87).

12 D. ŻoŁądź-Strzelczyk, Dziecko $w$ dawnej Polsce, Poznań 2002, s. 21.

${ }_{13}$ M. KoczersKa, Rodzina szlachecka w Polsce późnego średniowiecza, Warszawa 1975, s. 131-132.

${ }^{14}$ W XVI w. doszło na Litwie do powstania trzech kolejnych kodyfikacji w postaci Statutów Litewskich: I (1529 r.), II (1566 r.), III (1588 r.). 
ne były tam wcześniej za mienie ojca, ale statut litewski z 1529 r. dokonał istotnych zmian w tym zakresie. Ojciec przestał być panem życia i śmierci swych dzieci. Dzieciobójstwo zaczęło podlegać karze. Trzeci statut litewski z 1588 r. wprowadził surową karę dla ojca za zabicie własnego dziecka. Kara ta jednak była mniejsza niż za zwykłe zabójstwo, co uwidaczniało jednak potrzebę dalszej ochrony praw członków rodziny ${ }^{15}$. Późniejsze normy uchwalane przez sejm walny w XVI i XVII wieku, zwane konstytucjami, zawierały bardzo niewiele regulacji poświęconych stosunkom prawnym między rodzicami i dziećmi. Było to niewątpliwie spowodowane tym, że w obrębie zagadnień prywatnoprawnych dominowało nadal prawo zwyczajowe ${ }^{16}$.

Ten powoli kształtujący się proces tworzenia zalążków polskiego prawodawstwa, dotyczący między innymi instytucji władzy rodzicielskiej, musiał zostać zahamowany z uwagi na jego konfrontację z wielkimi zmianami we wszystkich dziedzinach życia społecznego, gospodarczego i ustrojowego, jakie niosła za sobą epoka Oświecenia. $\mathrm{Na}$ charakterystykę tej epoki składały się bowiem zarówno tragiczne dla Polski daty rozbiorów z 1772 r., 1793 r. i 1795 r., ale także długo oczekiwane reformy z lat sześćdziesiątych XVIII wieku, jak również dorobek Sejmu Czteroletniego z Konstytucją z 3 maja 1791 r. na czele ${ }^{17}$. Mimo iż te przemiany społeczno-polityczne były bardzo postępowe $^{18}$, to jednak dotkliwe ciosy rozbiorów spowodowały, że Rzeczpospolita zniknęła na pewien czas z mapy politycznej Europy. Rozbiory te przerwały również rozwój prawa rodzimego, które w XVIII wieku zaczęło być ujmowane w projektach nowoczesnych ko-

15 D. ŻoŁąDź-STRZELCZYK, op. cit., s. 22.

16 Por. J. Bardach, B. LeŚnodorski, M. Pietrzak, op. cit., s. 187-190.

17 K. Krassowski, M. Krzymkowski, K. Sikorska-Dzięgielewska, J. Walachowicz, Historia ustroju państwa, Poznań 1994, s. 148.

18 J. BARdach, B. LeŚNOdorski, M. PIeTRZAK, op. cit., s. 286-287. 
deksów ${ }^{19}$. Państwa rozbiorcze ${ }^{20}$, już w kilka lat po rozbiorach, wprowadziły swoje ustawodawstwa na ziemie polskie. Tak więc przez ostatnie lata XVIII wieku i pierwsze lata XIX wieku ziemie polskie znalazły się pod rządami pięciu kodyfikacji ${ }^{21}$. Każdy z tych kodeksów, tj. austriacki Allgemeines Bürgerlisches Gesetzbuch (ABGB) ${ }^{22}$, niemiecki Bürgerliches Gesetzbuch (BGB) ${ }^{23}$, rosyjski Swod Zakonow ${ }^{24}$, francuski Kodeks Napoleona oraz Kodeks Cywilny Królestwa Polskiego $(\mathrm{KCKP})^{25}$, stanowił wówczas element swoistego systemu prawnego, który istniał na ziemiach polskich i obowiązywał na terytorium danego zaboru.

19 Por. T. JаKuBowsKi, Prawo rzymskie $w$ projektach kodyfikacyjnych polskiego oświecenia, «Acta Universitatis Lodziensis, Folia Iuridica» $1984 \mathrm{nr} 15$, s. 47113. Autor ten w swym artykule cytuje fragmenty kodyfikacji Stanisława Augusta, z których wynika, iż w zakresie władzy rodzicielskiej projekt ten nie wprowadzał żadnych rewolucyjnych zmian. Władza rodzicielska miała nadal przysługiwać przede wszystkim ojcu („Najpierwsza jest władza rodzicielska nad dziećmi. Rodzą się dzieci z familii, której ojciec jest głową").

${ }^{20}$ Państwami rozbiorczymi były Rosja, Austria i Prusy. Do Rosji wcielone zostały ziemie litewskie, białoruskie i ukraińskie. Austria, oprócz Małopolski południowej z Krakowem i północnej z Lublinem, zagarnęła dawne województwo ruskie ze Lwowem i Haliczem. Prusy zaanektowały Wielkopolskę i Prusy Królewskie oraz znaczną część Mazowsza z Warszawą włącznie (por. J. BARDACH, B. LeŚNOdorsKi, M. Pietrzak, op. cit., s. 341-452).

${ }^{21}$ E. Muszalski, Prawo cywilne obowiqzujace w bytym Królestwie Kongresowym, Warszawa 1932, s. 9.

${ }^{22}$ Kodeks w języku polskim: S. WróBlEWSKI, Powszechny austriacki kodeks cywilny z uzupetniajacymi ustawami i rozporzqdzeniami objaśniony orzeczeniami Sadu Najwyższego, Kraków 1914; F. Zoll, Prawo cywilne, IV: Prawo familijne i spadkowe, Poznań 1933.

${ }^{23}$ Kodeks w języku polskim: W. ZIELIŃSKI, Niemiecki kodeks cywilny obowiqzujący od 1 stycznia 1900 r., Bytom 1900.

${ }^{24}$ Kodeks w języku polskim: F. Bossowski, Prawo cywilne ziem wschodnich, Warszawa 1922.

${ }^{25}$ Oba kodeksy w języku polskim: S. ZaWADzKI, Prawo cywilne obowiqzujace w Królestwie Polskim, I, Warszawa 1860. 
2. Prawo polskie epoki rozbiorów

a) Uwagi ogólne

Według wszystkich obowiązujących w Polsce kodeksów dzielnicowych, dzieci podlegały władzy rodzicielskiej rodziców. Podobieństwo to thumaczone było m.in. historycznym rozwojem instytucji rodziny, która jako swoista komórka życia społecznego, znacznie starsza od państwa, opierała się pierwotnie na władzy monarszej naczelnika rodziny. Dopiero z upływem czasu państwo wytworzyło się z federacji takich właśnie rodzin, łączących się dla obrony przed wspólnym zagrożeniem. Państwo, po ukształtowaniu się jego struktury, ograniczyło władzę naczelnika rodziny, odbierając mu wszystkie atrybuty władzy zwierzchniej, ale pozostawiło rodzicom te uprawnienia, które potrzebne im były do pełnienia funkcji wychowawczych ${ }^{26}$. Zdaniem F. Bossowskiego, ,to pozostawienie rodzicom atrybucji wychowawczych w stosunku do dzieci, podyktowane było nie tylko poszanowaniem tradycji przez państwo, ale także i względami oportunistycznymi, gdyż dla rodziców bodźcem starania się i troski o dzieci jest miłość rodzicielska, a już ustawodawstwo Kazimierza Wielkiego i Statuty Litewskie wychodziły z tego słusznego zapatrywania, że «ojca w miłości do dzieci nikt nie przewyższy». Wzięcie natomiast przez państwo na swe barki wychowania dzieci obarczyłoby je ciężarem nad siły. W dodatku rodzice, znając swe dzieci i interesując się nimi, mogą w wychowaniu uwzględniać ich indywidualne właściwości, co przy wychowaniu masowym, byłoby znacznie utrudnione, a często wprost niemożliwe. Pozostawiając rodzicom wychowanie dzieci, państwo rozciaga przecież nadzór nad spełnianiem obowiązków wychowawczych przez rodziców"27, Wspólne wszystkim kodeksom dzielnicowym było również i to, że żaden z nich nie definiował pojęcia władzy rodzicielskiej, choć analiza przepisów w tej materii dawała podstawę do przyjęcia, iż władza rodzicielska stanowiła ogół obowiązków spoczywających na podmiotach uprawnionych do jej wykonywania

\footnotetext{
${ }^{26}$ F. Bossowski, Polskie prawo rodzinne, Poznań 1936, s. 3.

27 Tamże, s. 4.
} 
oraz praw im przysługujących względem dziecka, w celu wykonywania pieczy zarówno nad jego osobą, jak i majątkiem. Jeśli zaś chodzi o szczegóły, można było dostrzec w tych kodeksach wiele doniosłych różnic, np. co do zakresu władzy rodzicielskiej, czy sposobu wykonywania nadzoru przez państwa nad sprawowaniem tej władzy ${ }^{28}$.

b) Swod Zakonow

Chronologicznie pierwszą kodyfikacją był Swod Zakonow, obowiązujący na ziemiach zaboru rosyjskiego ${ }^{29}$ od 1840 roku $^{30}$. Ta rosyjska kodyfikacja prawa cywilnego, która powstała jeszcze w dobie absolutyzmu, regulowała problematykę dotyczącą instytucji władzy rodzicielskiej w sposób dość archaiczny, bo chociaż władza ta przysługiwała obojgu rodzicom, to jednak wobec władzy męża nad żoną głos ojca miał decydujące znaczenie. Zasadą była natomiast zupełna odrębność majątkowa pomiędzy rodzicami i dziećmi. Dzieci mogły bowiem nabywać dla siebie oddzielny majątek, a rodzice nie mieli na podstawie władzy rodzicielskiej ani prawa jego użytkowania, ani prawa zarządu. To ostatnie prawo mogło być przez rodziców uzyskane poprzez ustanowienie ich opiekunami ${ }^{31}$.

W kwestii ograniczenia władzy rodzicielskiej ustawodawca rosyjski wprowadził dość specyficzną regulację. Zgodnie bowiem z art. 179 Swodu Zakonow: „Władza rodziców nad osobą dziecka nie gaśnie lecz zostaje ograniczoną: skutkiem przyjęcia dzieci do szkoły publicznej, której przełożeństwo zastępuje wówczas przy ich wychowaniu miejsce rodziców; skutkiem oddania dzieci do służby, gdyż wstępując wówczas w nowe stosunki i biorąc przez to na siebie nowe obowiązki, nie mogą już pozostawać w dotychczasowej bezpośredniej zależności od rodziców; skutkiem zamążpójścia córki, ponieważ jedna osoba dwom nieograniczonym władzom jak rodzicielska i mężowska w zupełności wydołać nie może, a córka, porzuciwszy dom swój i poszedłszy za

${ }^{28}$ Tamże.

29 Ziemie zabrane Rzeczypospolitej przy I, II, III rozbiorze, w guberni Połtawskiej i Czernichowskiej oraz w okręgu Białostockim.

${ }^{30}$ Do 1840 r. na ziemiach tych obowiązywał III Statut Litewski.

31 F. Bossowski, Prawo cywilne, cit., s. 206. 
mężem, nie może pozostawać w takiej mierze w zależności od rodziców, jak inne dzieci, przy nich się znajdujące". Przesłanką ograniczenia władzy rodzicielskiej było więc wejście dziecka w różne stosunki prawnej zależności, z których wynikały faktyczne przeszkody w wykonywaniu władzy rodzicielskiej. Kodeks ten nie przewidywał natomiast ograniczenia władzy rodzicielskiej z uwagi na nienależyte jej wykonywanie przez rodziców. Pewne jednak regulacje ograniczające rodzicom ich władzę rodzicielską nad dziećmi określone były m.in. w art. 170 Swodu Zakonow, który stanowił, że ,rodzice nie mają prawa do życia dzieci i za zabójstwo ich są sądzeni i karani wedle prawa karnego" oraz w art. 169, zgodnie z którym, „rodzice nie mogą zmuszać dzieci do działań prawu przeciwnych lub do udziału w nich; dzieci w tym wypadku zostają zwolnione od obowiązku uległości wbrew swemu sumieniu, zwłaszcza w tem, co wymaga ich własnego rozsądzenia i woli”. Bardzo istotny, z punktu widzenia niniejszych rozważań, był również art. 165, który stanowił, że „rodzice dla poprawy dzieci upornych, swarliwych i nieposłusznych, mogą stosować domowe środki poprawcze. W razie ich bezskuteczności, rodzice mają władzę: niepełnoletnie dzieci w wieku od lat 10 do 17 oddawać do domów poprawczo-wychowawczych dla niepełnoletnich na podstawie porozumienia z instytucjami zawiadującymi takimi zakładami; wnosić skargi na dzieci do władz sądowych". Artykuł ten wprowadzał pewnego rodzaju ograniczenie władzy rodzicielskiej, stosowane tylko z inicjatywy rodziców, którzy mogli skorzystać z pomocy oferowanej przez ustawodawcę w przypadku kłopotów wychowawczych ze swoimi dziećmi ${ }^{32}$.

c) Kodeks Napoleona

Kodeks Napoleona regulował natomiast, przy milczącej aprobacie władz rosyjskich, także stosunki prawne w Królestwie Polskim ${ }^{33}$.

32 Tamże, s. 240-247.

${ }^{33}$ Kodeks Napoleona obejmował swoim zasięgiem terytorium Księstwa Warszawskiego, powstałego na mocy traktatu w Tylży zawartego przez Napoleona z Prusami w 1807 r., które obejmowało ziemie zagarnięte przez Prusy w II i III rozbiorze Rzeczypospolitej. Księstwo to, które znajdowało się pod panowaniem Francji, nie przetrwało nawet siedmiu lat. Na mocy bowiem postanowień kongresu wiedeńskiego z 1815 r. Prusy odzyskały część zachodnią Księstwa Warszawskiego nazywaną Wielkim 
W nim również instytucja władzy rodzicielskiej była zdominowana przez silną władzę ojcowska, bo mimo iż § 372 tego kodeksu przyznawał władzę rodzicielską obojgu rodzicom, to jednak już następny paragraf 373 stanowił, że „w ciagu trwania małżeństwa sam ojciec władzę tę sprawuje". Co prawda, chociaż żona na równi z mężem posiadała władzę rodzicielską, to jednak przez czas trwania małżeństwa jej władza ulegała zawieszeniu i jedynie w wyjątkowych sytuacjach mogła zostać „odwieszona”, np. gdy mąż doznawał przeszkód w jej wykonywaniu. Rola matki w sprawowaniu władzy rodzicielskiej ograniczała się tylko do prawa i obowiązku pieczy nad osobą dziecka. Wyłączny zarząd majątkiem dziecka sprawował zaś tylko ojciec. Niezwykle istotne było natomiast to, że Kodeks Napoleona, choć uważany w chwili swego wydania za kodyfikację bardzo nowoczesną, nie zawierał pierwotnie żadnych przepisów dotyczących ograniczenia władzy rodzicielskiej ${ }^{34}$. Możliwość takiego ograniczenia władzy rodzicielskiej mocą odpowiedniego wyroku sądowego wprowadziła dopiero ustawa z 1898 r. ${ }^{35}$, która w przypadku, gdy rodzic sprawujący władzę rodzicielską nad dzieckiem źle go traktował lub zadawał mu rany, porzucał je, lub skłaniał do żebraniny, zezwalała sędziemu na odebranie mu prawa dozoru bez konieczności rozciągnięcia tego ograniczenia w stosunku do pozostałych dzieci. Dozór ten był zaś zgodnie z § 374 Kodeksu Napoleona obowiązkiem i prawem wyłącznej władzy określania miejsca pobytu dziecka. Jedyną przesłanką ograniczenia władzy rodzicielskiej było zatem nienależyte wykonywanie tej władzy przez rodziców.

Księstwem Poznańskim, a z pozostałych ziem Księstwa Warszawskiego utworzono Królestwo Polskie (zwane potocznie Królestwem Kongresowym bądź Kongresówką) połączone unią personalną z Rosją. Kodeks Napoleona wszedł w życie z dniem 1 maja 1808 r. i, mimo klęski Napoleona w wyniku wkroczenia wojsk rosyjskich, regulował również stosunki prawne Królestwa Polskiego. Kodeks Napoleona został w 1825 r. częściowo uchylony przez Kodeks Cywilny Królestwa Polskiego, obowiązujący na terenie Królestwa Kongresowego (por. J. Bardach, B. Leśnodorski, M. PietrzaK, op. cit., s. 341-415).

34 E. Muszalski, Kodeksy cywilne obowiqzujace na Ziemiach Centralnych Polski, Warszawa 1936, s. 153-154.

${ }^{35}$ K. LutostańsKi, op. cit., s. 118. 
Nie chodziło tu przy tym o dobro dziecka, ale o stwierdzenie konkretnych naruszeń po stronie rodziców. Zgodnie z tym przepisem, w centrum zainteresowania sądu było bowiem nie dobro dziecka, a kontrola prawidłowości wykonywanej przez rodziców władzy rodzicielskiej. Wymienione przez ustawę naruszenia rodziców względem dzieci, były jedynie dowodem nienależytego wykonywania władzy rodzicielskiej i stanowily podstawę do ingerencji sądu w jej zakres ${ }^{36}$.

d) Kodeks Cywilny Królestwa Polskiego

Moc obowiązująca Kodeksu Napoleona na ziemiach Królestwa Polskiego została uchylona przez uchwalony w 1825 r. Kodeks Cywilny Królestwa Polskiego. Kodeks ten, podobnie jak jego francuski poprzednik, przyznawał władzę rodzicielską obojgu rodzicom. Jednak zgodnie z § $337 \mathrm{KCKP}$, ,w ciagu pożycia małżeńskiego, oboje rodzice sprawują władzę rodzicielską; w razie jednak różnicy zdań, zdanie i wola ojca przeważa". Ta przewaga woli i zdania ojca miała zastosowanie tylko w przypadku wspólnego pożycia małżonków. W przypadku braku takiego pożycia sąd mógł zostawić dziecko przy matce tylko wówczas, gdy wymagała tego tzw. „korzyść” dziecka. Również i w KCKP pozycja prawna matki ograniczała się tylko do prawa i obowiązku pieczy nad osobą dziecka ${ }^{37}$.

W kwestii zaś modyfikacji przysługującej rodzicom władzy rodzicielskiej należy zwrócić uwagę na treść $§ 339$ KCKP, który regulował coś na kształt późniejszej instytucji ograniczenia władzy rodzicielskiej. Zgodnie bowiem z tym paragrafem, „rodzice, mając powody nieukontentowania z postępków swych dzieci, mogą karcić je sposobem zdrowiu ich i postępowi w naukach nieszkodliwym. Rodzice jednak nadużywający swej władzy sposobem zdrowiu dzieci szkodliwym, powinni być przez sąd ziemski (Trybunał Cywilny) przy zamkniętych drzwiach napomnieni, i na drogę łagodniejszego obchodzenia się naprowadzeni. Za powtórnem wykroczeniem, a nawet w miarę obciążających okoliczności i grożącego niebezpieczeństwa, ma im być władza

\footnotetext{
36 Por. L. Górnicki, Prawo cywilne w pracach Komisji Kodyfikacyjnej Rzeczypospolitej Polskiej w latach 1919-1939, Wrocław 2000, s. 258.

${ }^{37}$ K. LutostańsKi, op. cit., s. 105.
} 
rodzicielska odjęta, a opieka nad dzieckiem lub dziećmi, komu innemu, na koszt wykraczającego ojca lub matki poruczona". Przesłanką ograniczenia władzy rodzicielskiej było zatem ustalenie, że rodzice nadużywali swej władzy w taki sposób, że zagrażało to dobru ich dzieci. Celem łatwiejszego dokonania tych ustaleń, ustawodawca nałożył nawet na krewnych rodziców obowiązek informowania Prokuratora Królewskiego przy właściwym sądzie ziemskim o wszelkich przejawach nienależytego wykonywania przez rodziców ich władzy nad dziećmi (§ $340 \mathrm{KCKP}$ ). Można śmiało powiedzieć, że w zakresie prawnej regulacji instytucji ograniczenia władzy rodzicielskiej KCKP poszedł o krok dalej aniżeli Kodeks Napoleona, bo choć utrzymał on w zasadzie silną władzę ojcowską, to jednak przesunął jej punkt ciężkości w interesie zapewnienia należytej opieki nad dzieckiem.

e) Allgemeines Bürgerliches Gesetzbuch

Allgemeines Bürgerliches Gesetzbuch obowiązywało na ziemiach zaboru austriackiego od stycznia 1812 r. do końca 1914 r. Zgodnie z tym kodeksem, władza rodzicielska przysługiwała obojgu rodzicom, $\mathrm{z}$ tym jednak zastrzeżeniem, że czołową postacią w rodzinie był nadal ojciec. To do jego wyłącznych prerogatyw należało sprawowanie szeroko pojmowanej władzy rodzicielskiej. Zresztą ABGB charakteryzowało się najbardziej dyskryminującym matkę stanowiskiem w zakresie sprawowania władzy rodzicielskiej. Dyskryminacja ta przejawiała się przede wszystkim w tym, że matka w żaden sposób nie mogła przejać tej władzy po ojcu, gdy ten zmarł lub doznawał przeszkód w jej sprawowaniu ( $\$ 176$ ABGB). W obu tych przypadkach ustanawiano bowiem opiekuna. Pomimo iż § 139 ABGB stanowiło, że „,rodzice obowiązani są w ogólności wychowywać swoje ślubne dzieci, to jest: mieć staranie o ich życie i zdrowie, dać im przyzwoite utrzymanie, rozwijać ich fizyczne i umysłowe władze, a przez naukę religii i pożytecznych wiadomości założyć podstawę do przyszłego ich szczęścia”, co mogłoby wskazywać na ich równorzędną rolę w kwestii wykonywania władzy rodzicielskiej, to jednak z analizy kolejnych paragrafów wynikało, że to do ojca przede wszystkim należał obowiązek utrzymania dzieci, a rola matki ograniczała sięjedynie do „starania 
o ciało i zdrowie dzieci" ( $§ 141$ ABGB). Potwierdzał to dobitnie $\S 147$ ABGB stanowiąc, że: ,prawa, które służą przede wszystkim ojcu jako głowie rodziny, stanowią władzę ojcowską". W związku z tak marginalną pozycją matki na gruncie przepisów prawa, ustawodawca austriacki instytucję ograniczenia władzy rodzicielskiej, określoną w $§ 178$ ABGB, zastosowal tylko pod adresem ojca. Przepis ten stanowił, że ,jeżeli ojciec nadużywa swej władzy, albo nie dopełnia złączonych z nią obowiązków, albo jeżeli dopuści się postępowania hańbiącego lub nieobyczajnego (np. ojciec żyje w konkubinacie), wtedy nie tylko dziecko, ale każdy, kto się o tym dowie, w szczególności najbliżsi krewni, mogą żądać pomocy sądowej. Sąd zbada przedmiot zażalenia i wyda stosowne zarządzenia; może w szczególności zarządzić, że ojciec co do zarządu majątkiem, albo co do pieczy nad osobą dziecka ma być poddany nadzorowi sądu i zrównany z opiekunem". W świetle takiej regulacji, niewielkie znaczenie miał zatem fakt, iż z § 178a ABGB można było pośrednio wyprowadzić wniosek, że władza rodzicielska mogła zostać ograniczona również matce, wskutek jej zaniedbań. Przepis ten stanowił bowiem, że ,jeżeli zakład albo stowarzyszenie dla ochrony lub pielęgnowania dzieci objęły pielęgnowanie i wychowanie dziecka dręczonego, opuszczonego, zaniedbanego, albo takiego, któremu rodzice (podkreślenie moje - I.D.) nie dają potrzebnego nadzoru i wychowania, natenczas sąd opiekuńczy na wniosek zakładu lub stowarzyszenia po zbadaniu stanu rzeczy i wysłuchaniu rodziców może orzec, że przed ukończeniem wychowania nie wolno bez owego zezwolenia odebrać dziecka z zakładu lub stowarzyszenia wbrew tychże woli". Podsumowując, należy stwierdzić, że zgodnie z cytowanym już § 139 ABGB, generalną zasadą wykonywania władzy rodzicielskiej było wyraźnie dobro dziecka, określone w tym przepisie przez cel działań rodziców, którzy powinni stwarzać dzieciom podstawy do przyszłego szczęścia przez fizyczny i duchowy ich rozwój ${ }^{38}$.

f) Bürgerliches Gesetzbuch

„Najmłodszą” ze wszystkich kodyfikacji, obowiązujących na ziemiach polskich, było uchwalone w 1896 r. Bürgerliches Gesetzbuch.

${ }^{38}$ Por. E. TILl, Prawo prywatne austriackie, Lwów 1902, s. 282-283. 
Kodeks ten, już w momencie swego wejścia w życie, tj. z dniem 1 stycznia 1900 r., objął swym zasięgiem całe ziemie zaboru pruskiego. Mimo swej nowoczesności, w kwestii władzy rodzicielskiej BGB niczym istotnym się nie wyróżniało. Nadal władza rodzicielska przysługiwała w bardzo szerokim zakresie tylko ojcu (pełna władza nad osobą i majątkiem dziecka). To do niego należało również decydujące zdanie praktycznie we wszystkich sferach życia dziecka ${ }^{39}$. Niezwykle nowatorska była natomiast sama systematyka wprowadzona przez niemieckiego ustawodawcę do rozdziału dotyczącego władzy rodzicielskiej. Rozdział ten został mianowicie podzielony na część zawierającą przepisy dotyczące władzy rodzicielskiej ojca i część normującą władzę rodzicielską matki. Nie wgłębiając się w lekturę tych przepisów, można byłoby sądzić, że prawa tych podmiotów były równe w zakresie przysługujących im uprawnień i ciążących na nich obowiązków. Nic bardziej mylnego. Władza matki sprawowana u boku męża, zgodnie z § 1634 BGB, ograniczała się jedynie do troski o osobę dziecka, nie obejmowała natomiast jego majątku. Gdy ojciec nie mógł wykonywać władzy ojcowskiej z powodu przeszkody faktycznej lub jeżeli jego władza „spoczywała”"40, władza rodzicielska przechodziła wówczas na matkę (§ 1685 BGB). Pełnia władzy rodzicielskiej służyła matce również wtedy, gdy ojciec zmarł albo został uznany za zmarłego lub jeżeli utracił władzę rodzicielską (§ 1684 BGB).

W takim stanie rzeczy nie dziwi zatem fakt, iż instytucja ograniczenia władzy rodzicielskiej zawarta $\mathrm{w} \S 1666$ BGB dotyczyła tylko i wyłącznie ojca. Zgodnie z tym paragrafem, ,jeżeli duchowe lub cielesne dobro dziecka przez to na niebezpieczeństwo jest narażonem, że ojciec prawa pieczy o osobę dziecka nadużywa, dziecko zaniedbuje lub dopuszcza się hańbiącego albo niemoralnego prowadzenia, natenczas

39 F. Zoll, Prawo cywilne byłej Dzielnicy Pruskiej, Prawo familijne, III, WarszawaKraków 1922, s. 32-33.

${ }^{40}$ Instytucję ,spoczywania” władzy rodzicielskiej regulował § 1676 BGB, który jako prawną przyczynę „spoczywania” tej władzy wskazywał niezdolność oraz ograniczoną zdolność ojca do czynności prawnych, a także § 1677 BGB stanowiący, że przesłanką, ,spoczywania” władzy rodzicielskiej były także istotne przeszkody natury faktycznej (por. F. Zoll, Prawo cywilne byłej Dzielnicy Pruskiej, cit., s. 36-37). 
winien sąd opiekuńczy zarządzić środki do odwrócenia niebezpieczeństwa potrzebne. Sądowi opiekuńczemu mianowicie wolno rozporządzić, aby dziecko w celu wychowywania go w odpowiedniej rodzinie albo we wychowawczym lub też poprawczym zakładzie było umieszczonem. Jeżeli ojciec prawo dziecka o dawanie utrzymania nadwerężył i obawiać się należy, że utrzymanie na przyszłość, na niebezpieczeństwo narażonem będzie, natenczas można ojcu odebrać tak zarząd, jak i użytkowanie". Dokonując analizy tej instytucji należy stwierdzić, iż ustawodawca niemiecki wprowadził dwie przesłanki ograniczenia władzy rodzicielskiej, których kumulatywne spełnienie pozwalało na ingerencję sądu opiekuńczego w zakres wykonywanej przez ojca władzy rodzicielskiej. Przesłankami tymi, używając współczesnego języka, były: zagrożenie dobra dziecka oraz nienależyte wykonywanie przez ojca władzy rodzicielskiej, tak w stosunku do osoby, jak i do majątku dziecka. W tym miejscu nasuwa się pytanie, jaki wpływ na władzę rodzicielską matki miało ograniczenie władzy rodzicielskiej ojca? Odpowiedź na to pytanie jest dość zaskakująca, bo po dokonaniu całościowej analizy przepisów BGB dotyczących władzy rodzicielskiej należy stwierdzić, że ograniczenie władzy rodzicielskiej ojca pociagało za sobą faktyczne ograniczenie władzy rodzicielskiej matki. Chociaż przepisy niemieckiego kodeksu cywilnego wyraźnie o tym nie stanowiły, to jednak charakter wydawanych przez sąd opiekuńczy zarządzeń ograniczających władzę rodzicielską ojca, np. polegających na umieszczeniu dziecka w odpowiedniej rodzinie, zakładzie wychowawczym lub poprawczym, musiał pociagać za sobą również ograniczenie władzy rodzicielskiej matki. Taka sytuacja stanowiła wyraźny przykład dyskryminacji matek na gruncie przepisów obowiązującego prawa, bo mimo iż niejednokrotnie doskonale wywiązywały się one ze swych funkcji rodzicielskich wobec potomstwa, to jednak ponosiły konsekwencje nienależytego wykonywania władzy rodzicielskiej przez swych mężów. Zresztą nie trzeba tu podawać żadnych przykładów praktycznych celem potwierdzenia niniejszych rozważań, wystarczy bowiem zapoznać się z przepisami BGB dotyczącymi władzy rodzicielskiej matki, z których wynikało jak trudno było matce uzyskać władzę rodzicielską nad dzieckiem w przypadku różnych prze- 
szkód w jej wykonywaniu po stronie ojca i jak wieloma warunkami ta możliwość była obwarowana. Pozytywnie natomiast ocenić należy fakt, iż ustawodawca niemiecki, poza fizycznym aspektem pojęcia dobra dziecka, dostrzegł również jego duchowe pierwiastki, czemu dał wyraz redagując $\S 1666 \mathrm{BGB}^{41}$.

Wskazane powyżej kodyfikacje obowiązujące na ziemiach polskich w okresie zaborów były, jak zresztą całe ówczesne prawo rodzinne XIX wieku, przesycone pierwiastkami wywodzącymi się jeszcze z epoki feudalizmu, a w szczególności elementami patriarchalnymi ${ }^{42}$. Dopiero u schyłku XIX wieku, pod wpływem liberalizacji przepisów prawa i przy jednoczesnym wzroście ingerencji państwa w sferę stosunków rodzinnych, zaznaczyły się w prawie rodzinnym nowe, odchodzące od panujących stosunków patriarchalnych, tendencje. Wyrazem tego były kolejne nowelizacje poczynione w kodyfikacjach zaborowych, które przyznawały małoletnim liczne swobody w różnych sferach ich życia, np. w zaborze austriackim małoletni uzyskał prawo samodzielnego zobowiązywania się do świadczenia usług, a w zaborze pruskim, pozwolono mu natomiast na samodzielne prowadzenie przedsiębiorstwa zarobkowego. W takim stanie rzeczy, nie można było już więc mówić o niczym nieograniczonej władzy rodziców, a zwłaszcza ojca. Dzięki bowiem tym kolejnym swobodom sankcjonowanym przez prawo na rzecz dzieci, władza rodzicielska sprawowana przez rodziców uległa drastycznym ograniczeniom ${ }^{43}$.

3. Przesłanki ograniczenia władzy rodzicielskiej w prawie polskim w okresie międzywojennym

Po zdobyciu przez Polskę niepodległości w 1918 r. obowiązywały nadal wszystkie dotychczasowe kodeksy państw zaborczych, stanowiąc jedynie od tej daty polskie prawo dzielnicowe. Istniejący zatem

${ }^{41}$ Por. M. SIEJA, Instytucja władzy rodzicielskiej nad dziećmi ślubnymi w okresie zaborów i w Polsce niepodległej, «Acta Universitatis Wratislaviensis, Prawo» $2004 \mathrm{nr}$ 290, s. 148.

42 Tamże, s. 143.

${ }^{43}$ K. SóJKA-ZielińsKa, Historia prawa, Warszawa 2001, s. 265. 
do tej pory porządek prawny nie uległ żadnym zmianom ${ }^{44}$. Taki stan rzeczy nie budził jednak zdziwienia, ponieważ trudno było oczekiwać, by państwo polskie, po ponad 120 latach niewoli, odbudowało z dnia na dzień swój rodzimy system prawny. Jednakże pierwsze próby ustawodawcze $\mathrm{w}$ zakresie zmian $\mathrm{w}$ regulacji instytucji władzy rodzicielskiej podjęła, tuż po dacie odzyskania niepodległości, powołana przez Sejm Ustawodawczy Komisja Kodyfikacyjna, której celem było przygotowanie projektów jednolitego ustawodawstwa cywilnego i karnego. $\mathrm{Na}$ forum tej Komisji trwały intensywne prace również nad kodyfikacją prawa rodzinnego ${ }^{45}$. W jej ramach powstał m.in. projekt osobowego i majątkowego prawa małżeńskiego opracowany przez Karola Lutostańskiego ${ }^{46}$, który - mimo iż nie wszedł w życie - oceniony został jako jeden z najbardziej postępowych w Europie. Podstawowymi założeniami tego projektu były m.in.: całkowite równouprawnienie małżonków, mieszana forma zawarcia małżeństwa (cywilna lub kościelna ze skutkami w prawie cywilnym), dopuszczalność rozwodów, możliwość unormowania stosunków majątkowych między małżonkami na zasadzie umowy, ustawowy system majątkowy oparty na podziale dorobku między małżonkami ${ }^{47}$. W obrębie tej Komisji powstała również Podkomisja prawa o stosunkach z pokrewieństwa i opieki, na forum której prowadzono prace nad projektem przedstawionym przez Stanisława Gołąba ${ }^{48}$, który dotyczył stosunków prawnych

44 J. Ignatowicz, M. NazAr, Prawo rodzinne, Warszawa 2006, s. 27.

${ }^{45}$ Szerzej na temat genezy i powstania Komisji Kodyfikacyjnej, jej pozycji prawnoustrojowej, struktury, założeń oraz dalszych losów L. GóRNICKI, op. cit., s. 12-59.

46 Wybitny polski adwokat, specjalista prawa rodzinnego, profesor Uniwersytetu Warszawskiego, członek Towarzystwa Naukowego Warszawskiego, kierował Departamentem Ustawodawczym Ministerstwa Sprawiedliwości oraz Biurem Prac Kongresowych (por. Encyklopedia Powszechna PWN ${ }^{11}$, Warszawa 1982).

47 T. ŻeleńsKi (Boy), Nowa ustawa matżeńska. Piekło kobiet, Warszawa 1960, s. 196.

${ }^{48}$ Wybitny polski jurysta, profesor prawa cywilnego, a następnie procesu cywilnego Uniwersytetu Jagiellońskiego, uchodził za autorytet naukowy w kraju i za granica, gdzie był znany dzięki swym pracom opublikowanym w języku francuskim, włoskim, niemieckim i angielskim oraz jako członek czynny Międzynarodowego Instytutu 
pomiędzy rodzicami i dziećmi ${ }^{49}$. Zgodnie z art. 53 tego projektu: ,prawa rodzicielskie są wykonywane wyłącznie w interesie dzieci. Jeżeli rodzice nie pełnią należycie swych obowiązków, Państwowa Władza Opiekuńcza wyda zarządzenia konieczne do ochrony dobra dziecka. W razie trwałego zagrożenia dobra dziecka, władza odbierze je rodzicom i zarządzi odpowiednie umieszczenie przy innej rodzinie lub zakładzie. Koszta tego umieszczenia ponoszą rodzice, a gdy nie mają środków, osoby obowiązane do tego z mocy prawa publicznego". $\mathrm{W}$ art. 46 projektu zawarto natomiast ogólne zasady wykonywania władzy rodzicielskiej: „obowiązkiem jest rodziców sprawować zgodnie (władzę) pieczę nad małoletnimi dziećmi tak, jak tego ich dobro i wspólne dobro rodziny wymaga. Spory i zażalenia rozstrzyga Państwowa Władza Opiekuńcza" ${ }^{50}$. Nie trzeba w tym miejscu prowadzić skomplikowanych analiz, aby stwierdzić, że była to niezwykle postępowa propozycja zmian w zakresie władzy rodzicielskiej, zwłaszcza w stosunku do obowiązujących jeszcze de facto kodyfikacji z czasów zaborów. Cytowane artykuły były wyrazem stanowiska S. Gołąba, który uważał, że instytucje prawne z zakresu prawa rodzinnego powinny przede wszystkim zabezpieczać interes i dobro dziecka. Dlatego też autor ten zrezygnował z przyznania ojcu szerszego niż matce zakresu władzy rodzicielskiej.

W kwestii zaś instytucji ograniczenia władzy rodzicielskiej S. Gołąb zaproponował wprowadzenie dwóch przesłanek jej zastosowania, tj. nienależytego wykonywania obowiązków przez rodziców oraz zagrożenia dobra dziecka. Pomimo całej swej trafności, regulacje zawarte

Filozofii i Socjologii Prawa, z siedzibą w Paryżu (por. Encyklopedia Powszechna $P W N^{11}$, Warszawa 1982).

49 L. GóRnICKI, op. cit., s. 257-260 (por. zawarty w tej publikacji tekst projektu $\mathrm{z}$ uwzględnieniem zmian do niego wprowadzonych).

${ }^{50}$ Funkcję Państwowej Władzy Opiekuńczej, o której wspominały projekty Podkomisji prawa o stosunkach z pokrewieństwa i opieki, pełnić miał Urząd Opiekuńczy, tj. nowa instytucja unormowana w odrębnym projekcie. Zakres jej działania rozciągał się nie tylko na stosunki pomiędzy rodzicami a dziećmi, ale również na sprawy dotyczące opieki i kurateli nad małoletnimi oraz ubezwłasnowolnionymi (por. L. GóRNICKI, op. cit., s. 260). 
w art. 46 i 53 projektu nie zostały jednak zachowane w swej pierwotnej postaci. Po wprowadzeniu licznych zmian do projektu, miejsce tych artykułów zajął następujący zapis art. 38: „Małżonkowie sprawują wspólnie władzę rodzicielską. Obowiązkiem rodziców jest sprawować władzę rodzicielską tak, jak tego dobro dzieci i interes społeczeństwa wymaga".

Dokonując podsumowania należy stwierdzić, że w zakresie regulacji stosunków prawnych pomiędzy rodzicami i dziećmi projekt ten był bardzo postępowy i stanowił znaczące osiagnnięcie Komisji Kodyfikacyjnej. Jego twórcy doniosłą rolę przypisali opiece państwa nad małoletnimi dziećmi, stąd też zezwolono Państwowej Władzy Opiekuńczej na szeroką ingerencję w wykonywanie władzy rodzicielskiej. Prawa zaś i interesy dziecka postawiono na pierwszym miejscu ${ }^{51}$. Niestety, wybuch II wojny światowej nie pozwolił na kontynuację prac Komisji Kodyfikacyjnej. Mimo to jednak jej starania zostały docenione przez twórców późniejszych kodyfikacji, wyznaczając m.in. główne kierunki prac nad problematyką stosunków prawnych pomiędzy rodzicami i dziećmi. Nigdy już bowiem ustawodawca polski nie zdecydował się na przyznanie większych uprawnień rodzicielskich ojcu, jak również nie zrezygnował z zaproponowanych przez Komisję Kodyfikacyjną kryteriów należytego wykonywania władzy rodzicielskiej. Władza ta przysługiwała od tej pory na równi tak ojcu, jak i matce ${ }^{52}$.

4. Instytucja ograniczenia władzy rodzicielskiej w Polsce po zakończeniu II wojny światowej

Niedokończona w Polsce międzywojennej unifikacja stosunków między rodzicami i dziećmi została uwieńczona wydaniem $\mathrm{w}$ dniu 22 stycznia 1946 r. dekretu Prawo rodzinne ${ }^{53}$. W art. 40 tego aktu wprowadzono zapis stanowiący, że ,jeżeli rodzice przy wykonywa-

51 Por. L. Górnicki, op. cit., s. 267.

52 J. Strzebińczyk, Prawo rodzinne, Kraków 2003, s. 21; J. Winiarz, Prawo rodzinne, Warszawa 1980, s. 20.

${ }^{53}$ Dz.U. z 1946 r. Nr 6, poz. 52. 
niu władzy rodzicielskiej dopuszczają się zaniedbań lub czynów, które zagrażają poważnie dobru dziecka, władza opiekuńcza może wydać zarządzenia konieczne w celu usunięcia tych uchybień”. Takie sformułowanie przepisu było zbyt ogólne i zbyt mocno uzależniało interwencję „władzy opiekuńczej” od wyraźnie zawinionych zachowań rodziców. Wątpliwości budzi również użycie w jego treści słowa „może”, ponieważ w sytuacji ,poważnego zagrożenia dobra dziecka” wydanie przez sąd zarządzenia ograniczającego władzę rodzicielską powinno być bez wątpienia obligatoryjne ${ }^{54}$. Obok art. 40 należy również zwrócić uwagę na art. $20 \S 3$ dekretu z 1946 r., z którego wynikało, że „obowiązkiem rodziców jest sprawować władzę rodzicielską tak, jak tego wymaga dobro dzieci i interes społeczeństwa".

Kolejnym aktem prawnym, który zawierał problematykę ograniczenia władzy rodzicielskiej, była ustawa z dnia 27 czerwca $1950 \mathrm{r}$. Kodeks rodzinny ${ }^{55}$. W jej art. 60 polski ustawodawca wprowadził bowiem regulację, w myśl której: ,jeżeli rodzice nie sprawują należycie władzy rodzicielskiej, władza opiekuńcza, wyda odpowiednie zarządzenia. W szczególności władza opiekuńcza może poddać jedno lub oboje rodziców ograniczeniom, jakim podlega opiekun; może również powierzyć zarząd majątku dziecka kuratorowi”.

Z powyższego sformułowania wynika zatem, że jedyną przesłanką ingerencji „władzy opiekuńczej”, mającej na celu ograniczenie władzy rodzicielskiej, był fakt nienależytego wykonywania tej władzy przez rodziców. Taka sytuacja była ostro krytykowana w doktrynie. Podnoszono bowiem zgodnie, że błędem jest uniezależnianie kwestii uchybień rodziców od rzeczywistego zagrożenia dobra dziecka. Niewątpliwie, potrzeba takiego odwołania się do kryterium, jakim jest dobro dziecka, była spowodowana tym, że art. 54 Kodeksu rodzinnego stanowiąc, że „władza rodzicielska powinna być wykonywana tak, jak tego wymaga dobro dziecka i interes społeczeństwa” podniósł to poję-

${ }^{54}$ Por. H. Dolecki, Dobro dziecka a zarzqdzenia z art. 109 kro, «Acta Universitatis Wratislaviensis, Prawo» 1981 nr 102, s. 6.

55 Dz.U. z 1950 r. Nr 34, poz. 308 ze zm. 
cie, jak zresztą i art. 20 dekretu z 1946 r., do rangi jednego z kryteriów należytego wykonywania władzy rodzicielskiej ${ }^{56}$.

Artykuł 60 Kodeksu rodzinnego obowiązywał do czasu wejścia w życie ustawy z dnia 25 lutego 1964 r. Kodeks rodzinny i opiekuń$\mathrm{czy}^{57}$, który uchylił w całości Kodeks rodzinny z $1950 \mathrm{r}^{58} \mathrm{~W}$ nowej ustawie, problematyka ograniczenia władzy rodzicielskiej zawarta została w art. 109 k.r.o., który w swym pierwotnym brzmieniu stanowił, że ,jeżeli dobro dziecka jest zagrożone wskutek nienależytego wykonywania władzy rodzicielskiej, sąd opiekuńczy wyda odpowiednie zarządzenia. W szczególności sąd opiekuńczy może poddać jedno lub oboje rodziców takim ograniczeniom, jakim podlega opiekun; może również zarządzić umieszczenie dziecka w rodzinie zastępczej lub w zakładzie wychowawczym na koszt osoby obowiązanej do dostarczania dziecku środków utrzymania i wychowania; może także powierzyć zarząd majątkiem dziecka ustanowionemu przez siebie kuratorowi”. Takie sformułowanie tego przepisu wykazywało pewne podobieństwa do art. 60 uchylonego Kodeksu rodzinnego, ale także i pewne różnice ${ }^{59}$. Poza zmianą w postaci rozszerzenia katalogu możliwych do wydania przez sąd opiekuńczy zarządzeń ograniczających władzę rodzicielską, który i tak był tylko przykładowy, ustawodawca wprowa-

56 Por. B. Dobrzański, Kodeks rodzinny. Komentarz, Warszawa 1959, s. 557.

${ }^{57}$ Ustawa z dnia 25 lutego 1964 r. Kodeks rodzinny i opiekuńczy, Dz.U. z 1964 r. $\mathrm{Nr} 9$, poz. 59 ze zm.

${ }^{58}$ Początkowo, przepisy z zakresu prawa rodzinnego chciano potraktować jako część składową prawa cywilnego, dlatego ogłoszony w 1960 r. projekt Kodeksu cywilnego obejmował również te zagadnienia. Rozwiązanie to spotkało się jednak z dość powszechną krytyką. Przeważył ostatecznie pogląd, że prawo rodzinne stanowi odrębną gałąź prawa i jako takie powinno być skodyfikowane w osobnym akcie prawnym, tj. Kodeksie rodzinnym i opiekuńczym (por. M. RyBicki, Projekt Kodeksu rodzinnego na forum Sejmu, «PiP» 18.7/1963, s. 197-206).

${ }_{59}$ Warto podkreślić, że w art. 955 projektu Kodeksu cywilnego z 1960 r. jedyną przesłanką ograniczenia władzy rodzicielskiej było - na wzór art. 60 Kodeksu rodzinnego z 1950 r. - nienależyte jej wykonywanie przez rodziców. Pominięto natomiast zagrożenie dobra dziecka jako przesłanki takiego rozstrzygnięcia. Szerzej na ten temat K. JAGIELSKI, Krytycznie o ujęciu władzy rodzicielskiej w projekcie kodeksu cywilnego, «NP»16.11/1960, s. 1474-1477. 
dził dodatkową (w stosunku do art. 60 Kodeksu rodzinnego z 1950 r.) przesłankę ograniczenia władzy rodzicielskiej w postaci „zagrożenia dobra dziecka”. W takiej sytuacji, samo wystapienie stanu „zagrożenia dobra dziecka” nie zobowiązywało jeszcze sądu do wydania „odpowiednich" zarządzeń. Dopiero wykazanie, że stan ten wywołany został wskutek ,nienależytego wykonywania władzy rodzicielskiej” otwierało taką możliwość. Regulacja dotycząca kryteriów należytego wykonywania władzy rodzicielskiej została natomiast zawarta w art. 95 $\S 3$ k.r.o., który stanowi, że „władza rodzicielska powinna być wykonywana tak jak tego wymaga dobro dziecka i interes społeczny". Jak zatem wynika z niniejszych rozważań, na tle stale zmieniającej się regulacji dotyczącej ograniczenia władzy rodzicielskiej, wyznaczniki należytego wykonywania tej władzy, określone w art. $95 \S 3$ k.r.o. oraz w jego wcześniejszych odpowiednikach, pozostają wciąż niezmienne.

Na potwierdzenie powyższego stwierdzenia, należy zwrócić uwagę na kolejny etap w kształtowaniu się instytucji ograniczenia władzy rodzicielskiej, tj. na ustawę z dnia 19 grudnia 1975 r. o zmianie ustawy Kodeks rodzinny i opiekuńczy ${ }^{60}$. Na podstawie tej ustawy został zmieniony katalog przesłanek ograniczenia władzy rodzicielskiej zawarty $\mathrm{w}$ art. 109 k.r.o, który po wejściu w życie tej nowelizacji uzyskał następujące brzmienie: „§ 1. Jeżeli dobro dziecka jest zagrożone sąd opiekuńczy wyda odpowiednie zarządzenia". Przykładowy katalog zarządzeń sądu opiekuńczego został natomiast zamieszczony $\mathrm{w} \S 2$ tegoż przepisu. Rezygnacja przez ustawodawcę z dotychczasowej przesłanki „nienależytego wykonywania władzy rodzicielskiej” nadała instytucji ograniczenia tej władzy wybitnie profilaktyczny charakter, tj. uniezależniła tę formę ingerencji sądu opiekuńczego od tego, czy dobro dziecka jest zagrożone (naruszone) wskutek niewłaściwego (zawinionego bądź niezawinionego) zachowania rodziców, ich nieudolności, czy mylnego wyobrażenia o tym, czego wymaga dobro dziecka. Ustawa z 1975 r. nowelizująca Kodeks rodzinny i opiekuńczy jest - jak do tej pory - ostatnim etapem w kształtowaniu się instytucji ograniczenia władzy rodzicielskiej, co potwierdza niewattpliwie

${ }^{60}$ Dz.U. z 1975 r. Nr 45, poz. 234. 
fakt, że jedyną przesłanką tej formy ingerencji sądu opiekuńczego we władzę rodzicielską jest przez ponad 30 lat wyłącznie ,zagrożenie dobra dziecka" ${ }^{\prime}$.

Reasons for Restricting Parental in the Polish Lands

\section{Summary}

This article presents the limits of parental authority and, in particular, the condition of this limitation in historical perspective. The analysis of this institution begins the tenth century, and ends on the current Code and caring family. The primary objective of the article is to present the evolution of the institution of parental restrictions. Various stages of this evolution in Poland have been preceded by a brief general remarks on the regulation of this institution in Europe. The analysis serves primarily to a better understanding of the institution itself limits of parental authority, but also allows the presentation of the history of the Polish legal system over the centuries.

${ }^{61}$ Por. wyrok SN z dnia 7 czerwca 1967 r., III CR 84/67, «OSN» 1968 nr 2, poz. 21. 